\title{
Relationship between Teacher Education Students' Oral Communication Apprehensions in English and Their Academic Performance
}

\author{
Mark Anthony T. Juan and Ronald Candy S. Lasaten
}

\begin{abstract}
Using the descriptive-correlational research design, this study aimed to determine and analyze the correlation of the levels of oral communication apprehensions (CA) in English and academic performance of the teacher education students of Mariano Marcos State University, Laoag City, Philippines. The study used James McCroskey's Personal Report of Communication Apprehension (PRCA-24) to gather the needed data for the levels of CA. The general weighted average (GWA) of the respondents in subjects using English as medium of instruction were taken as data for their academic performance. Frequency counts, percentage, means, one-way analysis of variance (ANOVA), and t-test of difference between means of two independent samples were used to treat the data sets gathered. Findings show that the teacher education students have average levels of oral communication apprehensions in English in the different communication situations and that their academic performance has a mean described as Very Good. Additionally, the test of differences between the students' academic performance and their levels of oral CA indicate that for small group and public speaking situations, the grade averages have no significant differences, whether the students have low, average or high $\mathrm{CA}$ level in such situation. However, for classes, dyads and overall oral CA, the results indicate that those with low $\mathrm{CA}$ on those mentioned communication situations have significantly higher grade averages than their counterparts with average and high oral $\mathrm{CA}$ levels.
\end{abstract}

Index Terms-Academic performance, English language, oral communication apprehensions, teacher education students.

\section{INTRODUCTION}

Education has been regarded as the groundwork for progress and development in an increasingly diverse, complex, and globalized society.

Traditionally, the goal of schooling is to help students be prepared for full participation in society. However, the impact of globalization paves way for educational reforms that continually change and challenge the classrooms to be responsive to $21^{\text {st }}$ century education.

With this, as the classrooms become globalized, critical elements of $21^{\text {st }}$ century education have to be integrated to the teaching-learning process in order to adequately prepare learners for their expected roles in society. Two of these elements include the use of the English language and effective communication. Both aim for global participation and competitiveness.

Manuscript received February 20, 2016; revised June 15, 2016.

The authors are with the Mariano Marcos State University, College of Teacher Education (MMSU CTE), Laoag City, 2900, Philippines (e-mail: mark,juan@ymail.com, ronaldcandylasaten@yahoo.com.ph).
First, English language has been continuously promoted as a world-leading medium for communication that links parts of the world. The use of English language along various fields like that of business, travel, academics, and international politics has changed the ways in which people participate in society [1], [2]. Likewise, English is considered as the international lingua franca and using it for communication affords one with a necessary skill used in the context of an international community [3].

Accordingly, the importance of English has been emphasized in educational reforms and initiatives so as to suitably prepare students to be globally competitive. For example, the Framework for 21st Century Learning [4], lists English as one of the core subjects in the $21^{\text {st }}$ century. In the Philippine setting, English is one of the two official languages of the Philippines for communication and instruction [5]. Likewise, English is the medium of instruction in the Philippine educational system for core subjects like Science, Mathematics, and English [6].

Second, effective oral communication becomes essential to extend the knowledge of the English language from its written form to share ideas and insights to address the emerging concerns and challenges of today's globalized setting. Effective communication, along with collaboration, has been listed in the Framework for 21st Century Skills as one of the learning and innovation skills. Similarly, in the recent reform of the Philippine basic education system, the $\mathrm{K}$ to 12 Curriculum underscores that one of the new learning goals is the development of effective communication skills among Filipino students [7].

Ultimately, the success of all the educational reforms and globalization initiatives boils down to the basic unit of the educational system-the classroom. These classrooms are manned by teachers, who serve as facilitators of the teaching-learning process. Hence, preparing and training teacher education students is of crucial importance, especially along competency and skill areas related to $21^{\text {st }}$ century education literacies like that of using the English language and effective oral communication. This places the vital role to the Teacher Education Institutions (TEIs) in their preparation and training of the teacher education students, especially along content, pedagogical skills, and $21^{\text {st }}$ century skills.

Apparently, the preparation and training of teacher education students in the college classrooms is very crucial. Interestingly, numerous observations are shared by college professors that teacher education students have difficulties and apprehensions in expressing themselves using the English language during classes and even during encounters 
outside the classrooms. Majority are apprehensive to communicate their ideas during recitations, while some have anxieties in communicating during group, one-on-one and public speaking sessions.

Such is also a foregoing problem among teacher education students of the Mariano Marcos State University College of Teacher Education (MMSU-CTE), a Center of Excellence in Teacher Education in the Philippines. The teacher education students exhibit oral communication apprehensions in using English, especially when they engage themselves in reciting, group sharing, speaking in public and even conversing with people. Moreover, the researchers personally observed in their classes that teacher education students have evident apprehensions in expressing their ideas and communicating their thoughts in English during classroom discussions and interactions. Some of them even find it comforting to just remain passive throughout the class period than attempting to contribute ideas about the matters discussed.

Eventually, these communication apprehensions become detrimental to their academic performance and hinder them to become effective users and communicators of the English language, which may ultimately affect the quality of training and preparation they have.

In this context, this study identified and described the levels of oral communication apprehensions in English of the teacher education students along four communication situations and correlated them to their academic performance.

\section{OBJECTIVES OF THE STUDY}

This study was designed to determine, analyze, and correlate the level of oral communication apprehensions in English of the teacher education students and their academic performance. It is hoped that through this study, the teacher education students would be informed of their level of communication apprehensions in English so they can do necessary adjustments and explore possible ways to reduce their level of apprehensions, which can eventually improve their academic performance and at the same time maximize their teacher-training experiences.

\section{SigNIFICANCE OF THE STUDY}

Training and preparing teacher education students to become effective communicators in the classroom are helpful means of molding them to fit the role of a $21^{\text {st }}$ century educator. However, they are faced with oral communication apprehensions and anxieties, as well as challenges in using the English language, which must be identified and addressed in order to improve academic performance as well as to take full advantage of communication experiences.

Foremost, this study is beneficial to the teacher education students. When they are able to assess themselves and identify their level of oral communication apprehensions, they are able to reflect and look for remedies and interventions to solve such critical concerns, as well as to seek guidance from their mentors. With this, they could improve their oral communication in English in their respective classrooms and in their engagement to different communication situations. Eventually, they could enhance their academic performance as well as contribute to the formation of an interactive classroom setup where effective language use and communication abound.

Also, curriculum developers could be given insights to enrich existing teacher education curriculum subjects that focus on students as active communicators and not just as passive learners who are receivers of information. Also, they may find it essential to integrate English oral communication skills related to actual classroom situations to the subjects taught. In this effect, this could give the teacher education students a gradual exposure to their roles as effective communicators and eventually improve their performance in the classroom.

In addition, this study could provide college teachers, especially the English educators, some ideas on how to make their subjects promote oral communication and use of English to their students. In doing so, they could provide avenues for students to be progressively exposed on communicating their ideas, as well as in improving their fluency in English.

Likewise, teacher-training institutions could be afforded better insights on the continuous improvement of their flagship education programs, especially along being responsive to the demands of shifting educational landscapes, particularly on English language usage and effective communication of their teacher education students. If these institutions are sensitive to the communication apprehension concerns of the students, they could likely initiate steps to proactively address such.

Finally, this study could also inspire other research enthusiasts for further studies on skills of teacher education students focused on other subject areas.

\section{THEORETICAL AND CONCEPTUAL FRAMEWORK}

Primarily, this study is anchored on the Communication Apprehension Theory of James McCroskey [8]. The theory states that $\mathrm{CA}$ is apparent when an individual has a certain level of fear or anxiety connected with either real or expected communication with another person or persons.

Second, this study is also anchored on the Social Learning Theory of Lev Vygotsky [9] which points out that individuals learn as they interact and communicate with other people. Vygotsky examined the influence of social environments to the learning process.

Third, this study is pinned on the Experiential Learning Theory based on the early works of theorists Piaget, Lewin and Dewey but was popularized by David Kolb. According to [10], this type of learning can be defined as the process whereby knowledge is created through the transformation of experience. Experiential Learning Theory emphasizes how experiences influence the learning process.

Based on the theories, the study has come up with its conceptual framework as illustrated in Fig. 1. The figure relates academic performance to the oral communication apprehensions in English that teacher education students experience as they engage in classroom situations and in social dealings with students, teachers and other members of the school community. These apprehensions could possibly impose concerns not only to the teacher education students' communication skills but also to their academic performance. 


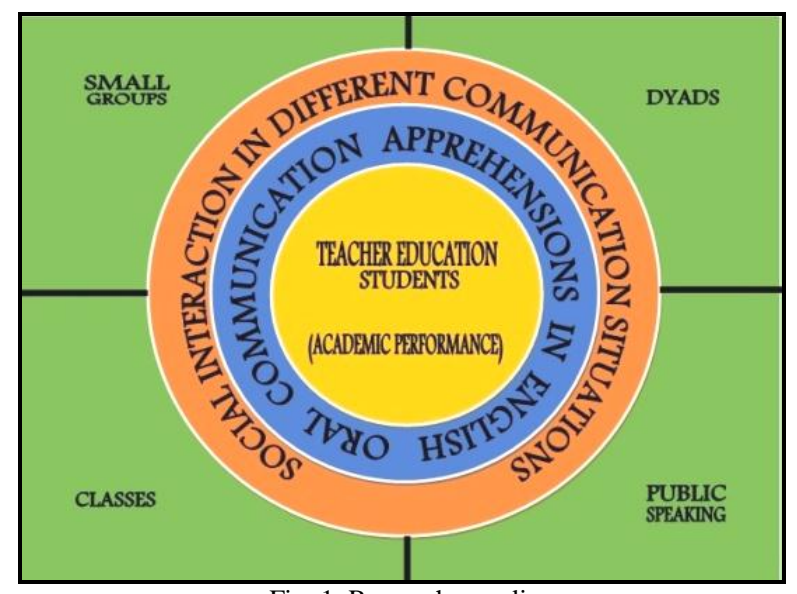

Fig. 1. Research paradigm.

\section{Methodology}

This study used the descriptive-correlational research design. This research design involves collecting information through data review and surveys and describing the way things are with respect to variables or conditions in a situation. In this study, the teacher education students' level of oral communication apprehensions in English in the four communication situations and their level of academic performance were identified, analyzed and correlated.

The respondents involved in the study were 128 third year Bachelor of Elementary Education (BEEd) teacher education students of the Mariano Marcos State University College of Teacher Education (MMSU-CTE) located in Laoag City, Philippines. They specialize in General Content and were officially enrolled for the first semester of school year 2014-2015, and were selected through random sampling.

To gather needed data for the study, a survey questionnaire called the Personal Report of Communication Apprehension (PRCA-24) by James McCroskey was used. The PRCA-24 is an instrument designed by McCroskey to help individuals assess their personal level of communication apprehension [11]. It is the most widely used instrument in college classes to assess student communication apprehensions. The instrument is designed to measure overall anxiety as well as anxiety in four different communication situations: small groups; meetings (or classes); dyadic situations; and public speaking.

The PRCA-24 was selected because of its wide use and its effective reliability and validity values [12], [13]. The PRCA-24 is internally consistent. Alpha reliability estimates for all 24 items range from 0.93 to 0.95 [14]. The instrument also demonstrates considerable stability across time; test-retest reliability coefficients greater than .80 have been reported [15].

The Personal Report of CA-24 (24 items) is structured in four groups of statements each: Statements 1 to 6 are related to oral communication in groups; Statements 7 to 12 are related to oral communication in meetings (or classes); Statements 13 to 18 are related to oral communication in dyads (couples); and Statements 19 to 24 are related to oral communication in public speaking [11].

Meanwhile, the level of English oral communication apprehensions of the teacher education students was based on the PRCA-24 results. The five responses were given numerical equivalents as: Strongly Agree (1); Agree (2); Undecided (3); Disagree (4); and Strongly Disagree (5). Afterwards, the scoring scheme [11] shown below was utilized to get the sub-scores and overall scores of the respondents.

$\begin{array}{ll}\text { Context } & \begin{array}{l}\text { Scoring } \\ \text { Small Group }\end{array} \\ & 5)+(\text { scores for items } 2,4, \& 6)-(\text { scores for items } 1,3, \& \\ \text { Classes } & 18+(\text { scores for items } 8,9, \& 12)-(\text { scores for items } 7,10, \\ & \& 11) \\ \text { Dyadic } & 18+(\text { scores for items } 14,16, \& 17)-(\text { scores for items } 13, \\ \text { Groups } & 15, \& 18) \\ \text { Public } & 18+(\text { scores for items } 19,21, \& 23)-(\text { scores for items } 20, \\ \text { Speaking } & 22, \& 24) \\ \text { Overall Score } & \text { Add all the four sub-scores }\end{array}$

After the sub-scores and overall scores were identified, they were interpreted. Score should range between 24 and 120. The general descriptions to people in each level of communication apprehensions [16] were used. They are as follow:

Interpretation
Hevel

In relation to the four communication situations, below is the norm chart for the PRCA-24 which is based on over 40,000 college students; data from over 3,000 non-student adults in a national sample provided virtually identical norms, within 0.20 for all scores.

$\begin{array}{lcccc} & \text { Mean } & \text { SD } & \text { High } & \text { Low } \\ \text { Total Score } & 65.5 & 15.3 & >80 & <51 \\ \text { Group Discussions } & 15.4 & 4.8 & >20 & <11 \\ \text { Meetings (Classes) } & 16.4 & 4.2 & >20 & <13 \\ \text { Dyads } & 14.2 & 3.9 & >18 & <11 \\ \text { Public Speaking } & 19.3 & 5.1 & >24 & <14\end{array}$

Meanwhile, data needed for the academic performance grades of the respondents were secured from the college registrar. The general weighted average (GWA) of each respondent for subjects using English as a medium of instruction was taken. Such subjects were undertaken by the respondents during the first semester of SY 2014-2015.

The data gathered were tabulated, interpreted and analyzed using statistical tools. For the level of academic performance of the students, the following GWA ranges and descriptions were used:

$\begin{array}{ll}\text { GWA Range } & \text { Description } \\ 1.00-1.24 & \text { Excellent } \\ 1.25-1.49 & \text { Highly Outstanding } \\ 1.50-1.74 & \text { Outstanding } \\ 1.75-1.99 & \text { Very Good } \\ 2.00-2.24 & \text { Good } \\ 2.25-2.49 & \text { Very Satisfactory } \\ 2.50-2.74 & \text { Satisfactory }\end{array}$


For the analysis of the academic performance of the respondents, frequency counts, percentage and mean were used. Meanwhile, for the correlation and tests of difference of the level of academic performance and levels of English oral communications of the teacher education students, the one-way ANOVA and t-test were employed. In all tests of significance, the level of significance was set at the .05 probability level.

\section{RESULTS AND DISCUSSIONS}

This section presents the results and findings of the study. It presents tables showing the levels of oral communication apprehensions in English of the teacher education students in different communications, the level of academic performance of the teacher education students, and the significant difference in the academic performance of the teacher education students when they are grouped according to level of oral communication apprehensions in English.

\section{A. Levels of Oral Communication Apprehensions in English of the Teacher Education Students}

Oral communication apprehensions can be observed among people although they vary on the extent or level in which the apprehensions manifest. Experiencing forms of anxiety in oral communication is a normal part of the communication process. Interestingly, many people assume that such apprehension is unique to them. However, it is a widely-shared experience among people at varying levels. Along this area of concern, Table I shows the result.

TABLE I. LEVELS OF ORAL COMMUNICATION APPREHENSIONS (CA) OF THE STUDENTS

\begin{tabular}{|c|c|c|}
\hline Communication Situations & Frequency (f) & Percentage (\%) \\
\hline \multicolumn{3}{|l|}{ Small Group Discussions } \\
\hline High & 3 & 2.34 \\
\hline Average & 109 & 85.16 \\
\hline Low & 16 & 12.50 \\
\hline Total & 128 & 100.00 \\
\hline \multicolumn{3}{|l|}{ Classes } \\
\hline High & 38 & 29.69 \\
\hline Average & 77 & 60.16 \\
\hline Low & 13 & 10.16 \\
\hline Total & 128 & 100.00 \\
\hline \multicolumn{3}{|l|}{ Dyads } \\
\hline High & 40 & 31.25 \\
\hline Average & 79 & 61.72 \\
\hline Low & 9 & 7.03 \\
\hline Total & 128 & 100.00 \\
\hline \multicolumn{3}{|l|}{ Public Speaking } \\
\hline High & 16 & 12.50 \\
\hline Average & 107 & 83.59 \\
\hline Low & 5 & 3.91 \\
\hline Total & 128 & 100.00 \\
\hline \multicolumn{3}{|l|}{ Overall Oral CA } \\
\hline High & 20 & 15.62 \\
\hline Average & 101 & 78.91 \\
\hline Low & 7 & 5.47 \\
\hline Total & 128 & 100.00 \\
\hline
\end{tabular}

It can be deduced from the results that in the small group discussion situation, $109(85.16 \%)$ of the teacher education students experience an average level of apprehension. This means that their communication apprehension in this context is similar to what most people experience. Some group discussions cause them to be anxious while other group discussions make them feel comfortable. Generally, these students like participating in group discussions. However, most of them experience nervousness and feel tense as they engage in this kind of communication situation.

Meanwhile, $16(12.50 \%)$ students experience a low level of apprehension while they participate in group discussions. They are the ones who are likely to be active in talking and communicating. These students like to participate or get involved in group discussions. Likewise, they generally feel calm and relaxed in joining this kind of communication situation.

The results imply that for the group discussion context, majority of the teacher education students, particularly those within the low and average levels, are likely to have been exposed to group discussions inside and outside of the classroom. Their teachers are able to employ the group discussion strategies to motivate them to share their ideas among themselves. Moreover, their group discussions could be involving their peers who are within their age level which fosters ease of idea sharing rather than inducing anxiety. Likewise, anxiety induced by group discussions may also be based on the type of grouping used. For example, for task-groups, which are generally used in the academic setting, they can cause more anxiety over a social group which is mainly for pleasure or enjoyment.

Moreover, only three $(2.34 \%)$ of the teacher education students have high level of apprehension while engaged in small group discussions. This means that they become low talkers and would actively avoid communicating. These students dislike getting involved in group discussions. They are tensed and uncomfortable engaging in this kind of communication situation. This implies that these students are not yet fully comfortable expressing their thoughts in group discussions which may be attributed to lack of proficiency of English, lack of motivation and confidence or just typical shyness.

Such result can be linked to research findings [17] that the main cause of students' lack of confidence is their low ability and proficiency in English. These are the students who need constant motivation for them to overcome their anxiety.

It can be gleaned from the same table that during classes, $77(60.16 \%)$ of the teacher education students experience average level of oral communication apprehension in English. This means that some class discussions cause them fear, while others give them ease. These students are usually comfortable participating in class interactions. However, they sometimes feel uncomfortable expressing their opinions in class due to a certain degree of nervousness. This implies that the teacher education students still experience considerable apprehensions when they participate in class discussions which could serve as a hindrance toward expressing their ideas and insights during class interactions.

It can also be noted that $38(29.69 \%)$ of the students have high level of apprehension that they avoid participating in class discussions, thus, becoming low talkers. These students are generally nervous when they have to participate in class. Likewise, they feel afraid to express their opinions in class and they feel uncomfortable communicating in class and are not relaxed when answering questions in class. Apparently, the formal structure of the classroom, combined with the pressure of having to display knowledge orally, may cause 
much anxiety. This could mean a serious threat that impedes the flow of discussion in class. These students are gripped by shyness and inadequate proficiency in English so they are not confident to express their ideas. Likewise, they are likely fearful to commit mistakes and be criticized by classmates. Indeed, these students are likely to avoid communication, thus, they have very few, if any, opportunities to share insights, clarify ideas, and express feelings. Moreover, their teachers are not able to give them feedback and appropriate guidance if they are reluctant to talk during the discussions. Being highly apprehensive in classes could also have a seemingly negative impact to academic performance and hinders them from becoming effective classroom communicators.

In connection, [18] cited that shyness could be a source of problem in students' learning activities in the classroom especially in the class of speaking. Likewise, [19] stated that students commonly stop from participating in speaking activities in class due to their fear of being criticized and laughed at by other students.

Meanwhile, only $13(10.16 \%)$ of the teacher education students have low level of apprehension, which indicates that they aggressively seek opportunities to participate in class discussions. These students are not frightened to participate in class discussions. They feel calm and relaxed in expressing their opinions and in answering questions. Class discussions make them comfortable; thus, they express their ideas interactively. The students who have low apprehensions are likely to express their ideas to maximize their classroom interactions as effective communicators in classrooms.

As regards dyadic situations, 79 (61.72\%) of the teacher education students experience average level of communication apprehension in English. This only means that these students still manifest apprehensions in some dyadic situations they participate into just like most of other people would likely do. Ordinarily, these students are calm and relaxed in conversations. However, there are instances when they are apprehensive to express their thoughts and ideas. This implies that the students experience anxiety when communicating face to face with somebody interpersonally. Within the academic setting, these teacher education students may engage in dyads when communicating with their classmates, teachers, school administrators, parents, and visitors, among others. But with the tinge of apprehension they experience, such interpersonal exchange of ideas can be marred by ambiguity. Also, if a these students are pressured of trying to make a good impression to the other person, such may also add to the anxiety they experience.

Further, $40(31.25 \%)$ students experience high level of apprehension in English when they communicate in dyads. This means that these students actively avoid communicating and remain low talkers. These are the students who feel very tense and nervous in conversations. They are the ones afraid to speak up and share ideas and thoughts interpersonally. This could pose a threat to the effective flow of idea exchanges. For instance, when facing a teacher one-on-one, these students experience anxiety because of uncertainty about how to react to the teacher or about how the teacher might respond. Also, the fear of committing mistakes and sending negative impressions to the other person could lead to the fear to communicate interpersonally, especially if the other person is perceived to be at a higher level proficiency of the language used.

The result can be linked to what [20] found out in his study that one of the primary reasons of fear of mistake is that students are afraid of looking foolish in front of other people and they are concerned about how others see them. In addition, [21] claims that students find it very intimidating to speak English in front of friends and a teacher. Moreover, not talking or actively avoiding communicating in dyads could possibly send negative thoughts of incompetence or rudeness to the other person.

Further, only nine $(7.03 \%)$ of the students have low level of apprehension in dyadic situations. This means that they are likely to be high talkers, who actively want to interpersonally communicate with someone. These students have no fear in speaking up in conversations and they are ordinarily very calm and relaxed in conversations.

When it comes to public speaking situation, 107 (83.59\%) of the teacher education students experience an average level of communication apprehension in English. These students feel anxiety in some public speaking situations. In some situations, these students feel relaxed while giving a speech. However, some public speaking situations cause certain of their body parts to be tense and rigid that leads them to confusion of thoughts. This only implies that these students are not yet generally exposed to engaging themselves in public speaking. Also, their teachers may not yet fully utilize public speaking as a strategy to maximize their teacher training and preparation. Likewise, the students are likely to find themselves in a conspicuous position in front of others, who will criticize them in what they have to say. Truly, their anxiety may be attributed to the nature of public speaking they get involved to. When they are given immediate notice to speak in public, they feel greater anxiety than when they have ample time to prepare for it.

Meanwhile, 16 (12.50\%) of the teacher education students experience high level of communication apprehension when they speak in public using English. This means that they likely avoid this kind of communication situation as much as possible. These students are not relaxed while giving a speech. Usually, certain parts of their body feel very tense and rigid and their thoughts become confused and jumbled that could cause them to forget facts they already know. For these students, this could simply undermine their teacher training to become effective communicators in class because of fear to speak in public which can be linked to shyness, fear of a large audience, low proficiency and confidence.

Significantly, [22] claims that speaking in front of people is one of the more common phobias that students encounter; the feeling of shyness makes their mind go blank or that they forget what to say. Moreover, [23] asserts that students who lack confidence about themselves and their English proficiency necessarily suffer from communication apprehension. Consequently, with the help of their teachers, these students need to gradually overcome their apprehensions in order to face and communicate with the public with confidence.

It can also be noted that only five $(3.91 \%)$ students have low level of apprehension in this communication situation. These students have no concerns in public speaking. They show ease and confidence and are likely to be high talkers in 
communicating. These students face the prospect of giving a speech with confidence and feel relaxed and fearless in giving a speech.

Overall, 101 (78.91\%) of the teacher education students have average level of oral communication apprehension, followed by $20(15.62 \%)$ who have high level of apprehension, while only seven $(5.47 \%)$ experience low level of communication apprehension in English.

Interestingly, only seven of them are high talkers and are likely to seek opportunities to communicate with others, while the rest have average level which makes them apprehensive in some situations and high level which makes them actively avoid engaging in communication situations.

Apparently, the said finding is similar to the findings of the studies previously conducted that communication apprehension is present among students but only at a moderate or average level [24]-[26].

With the nature of the teaching profession, teachers need to be actively involved in communication along different situations. Similarly, [27] stressed that a good teacher is a great communicator, while [28] underscored that teachers must be proficient communicators in different communication situations. The results imply that the teacher education students still have to improve their oral communication skills to reduce their apprehensions at a low level, especially when they go for practice teaching at the laboratory and field schools, which offer them various communication situations.

\section{B. Academic Performance of the Teacher Education Students}

Another concern of the study is to determine the academic performance of the teacher education students. Academic performance is the measure of how the students perform in their coursework, which encompasses varied learning activities that require different learning styles. In this regard, almost all of the students' academic activities require them to use their oral communication skills in English. The following Table II presents the result along this area of concern.

TABLE II: DISTRIBUTION OF THE STUDENTS ACCORDING TO THEIR ACADEMIC PERFORMANCE

\begin{tabular}{|c|c|c|c|}
\hline $\begin{array}{l}\text { Academic } \\
\text { Performance }\end{array}$ & Description & Frequency (f) & $(\%)$ \\
\hline $1.00-1.24$ & Excellent & 0 & 0.00 \\
\hline $1.25-1.49$ & Highly Outstanding & 4 & 3.13 \\
\hline $1.50-1.74$ & Outstanding & 25 & 19.53 \\
\hline $1.75-1.99$ & Very Good & 63 & 49.22 \\
\hline $2.00-2.24$ & Good & 29 & 22.66 \\
\hline $2.25-2.49$ & Very Satisfactory & 6 & 4.69 \\
\hline $2.50-2.74$ & Satisfactory & 1 & 0.78 \\
\hline $\begin{array}{l}\text { Total } \\
\text { Mean }=1.89(V)\end{array}$ & $=0.21$ & 128 & 100.00 \\
\hline
\end{tabular}

Evidently, 63 (49.22\%) obtained a GWA range of 1.75-1.99, which has a descriptive rating of very good, followed by $29(22.66 \%)$ with a GWA range of 2.00-2.24, which is described as good, and $25(19.53 \%)$ within the $1.50-1.74$ range, which is outstanding. Meanwhile, only four $(3.13 \%)$ are within the GWA range of 1.25-1.49 with a descriptive rating of highly outstanding.

On the other hand, six students $(4.69 \%)$ fall under the 2.25-2.49 range, which is described as very satisfactory, and one $(0.78 \%)$ for the $2.50-2.74$ range with a descriptive rating of satisfactory. None of the students obtained a GWA on the 1.00-1.24 range or those who are excellent in their academic performance. Meanwhile, the mean GWA of the students is 1.89 , with standard deviation of .21 , which is described as very good. The result indicates that majority of the students are within the average range of GWA.

\section{Differences in the Academic Performance of the}

Students When They are Grouped according to their Level of Oral Communication Apprehensions

The study also compared the academic performance of the teacher education students in the various levels of oral communication apprehensions in English. The one-way Analysis-of-Variance (ANOVA) was performed.

The following Table III shows the result of the t-test of difference between the academic performance of the students when they are grouped according to their level of oral communication apprehensions in English in the different communication situations.

TABLE III: RESULT OF THE T-TEST OF DIFFERENCE BETWEEN THE ACADEMIC PERFormance of THE Students When THEy ARE Grouped ACCORDING TO THEIR LEVEL OF ORAL COMMUNICATION APPREHENSIONS IN DIFFERENT COMMUNICATION SITUATIONS

\begin{tabular}{lccccc}
\hline \hline $\begin{array}{c}\text { Communication } \\
\text { Situations }\end{array}$ & $\begin{array}{c}\text { Level of } \\
\text { Oral } \\
\text { CA }\end{array}$ & $\mathbf{n}$ & Mean & F-value & Prob. \\
\hline Small Groups & High & 3 & $1.92^{\mathrm{a}}$ & & \\
& Average & 109 & $1.91^{\mathrm{a}}$ & 2.22 & .113 \\
& Low & 16 & $1.79^{\mathrm{a}}$ & & \\
\hline Classes & High & 38 & $1.93^{\mathrm{b}}$ & & .045 \\
& Average & 77 & $1.90^{\mathrm{b}}$ & $3.14^{*}$ &. \\
& Low & 13 & $1.76^{\mathrm{a}}$ & & \\
& High & 40 & $1.99^{\mathrm{b}}$ & & .000 \\
& Average & 79 & $1.87^{\mathrm{b}}$ & $10.07^{* *}$ & \\
\hline Dyads & Low & 9 & $1.68^{\mathrm{a}}$ & & .590 \\
& High & 16 & $1.94^{\mathrm{a}}$ & & \\
\hline Public Speaking & Average & 107 & $1.89^{\mathrm{a}}$ & .530 & \\
& Low & 5 & $1.86^{\mathrm{a}}$ & & .000 \\
& High & 20 & $2.02^{\mathrm{b}}$ & & \\
\hline Overall Score & Average & 101 & $1.88^{\mathrm{b}}$ & $10.60^{* * *}$ & \\
& Low & 7 & $1.62^{\mathrm{a}}$ & & \\
\hline
\end{tabular}

$* * P<.01$ Note: Means with the same letter superscripts are not significantly different.

$* P<.05$

It can be deduced from the results that for the small group situation, students with high CA have a mean grade of 1.92 , students with average CA obtained a mean grade of 1.91 and those with low CA have a mean grade of 1.79 . Their mean grades are not significantly different as indicated by the F-value of 2.22 with a probability of .113 , which is greater than the .05 level of significance. This implies that the students do not vary in their academic performance whether they have high, average or low oral communication apprehension in English for small group situations.

As regards classes, the results reveal that the mean grades of the teacher education students are 1.93 for high CA, 1.90 for average CA and 1.76 for low CA with an F-value of 3.137 at the .045 probability, which is lesser than .05 level of significance. The grade average of the students with low CA is significantly different from the other two levels. This implies that the students with low CA for classes are likely to perform better academically. This supports the findings of [16] that students with low CA tend to perform better than those with high CA. 
In terms of dyads, it can be gleaned from the table that the mean grade for students with high CA is 1.99. Meanwhile, those with average $\mathrm{CA}$ have a mean grade of 1.87 , while those with low CA obtained a mean grade of 1.68. The results indicate that the grade average of low apprehensive students in dyads has a significant difference from the grade average of the students who have high and average CA levels as indicated by an F-value of 10.07 with a probability of .000 , which is less than the .01 level of significance. The results imply that students with low CA perform better academically than their counterparts in the other levels in terms of dyadic situations. This is in congruence to the findings of [29] that students with low CA outperform those with high apprehensions who have poor communication skills.

Considering the public speaking situation, table shows that the mean grade of the students are 1.94 for high CA, 1.89 for average CA, and 1.86 for low CA. The results show that the mean grades are not significantly different as indicated by the F-value of .530 at .590 probability which is greater than .05 level of significance.

Meanwhile, for the overall CA, the results show that the mean grade of the students with high CA is 2.02 , while those with average $\mathrm{CA}$ is 1.88 , and those with low $\mathrm{CA}$ is 1.62 . The results indicate that the grade average of low apprehensive students is significantly different from the grade average of the students with high and average CA levels as indicated by the F-value of 10.60 at .000 probability, which is less than the .01 level of significance. This implies that students with low CA have higher academic performance as compared to the students with high and average CA levels.

The results corroborate with the finding of [30] that the Grade Point Average (GPA) of students with high CA is significantly lower than those students with low CA. Such results are also in congruence with the finding of [29] that students with apprehensions and poor communication skills are often expected to have lower grade point averages.

The results further imply the need to expose the teacher education students to more oral communication activities in order for them to reduce their high and average apprehensions. As teacher education students, they are expected to have low oral communication apprehensions due to their expected roles as classroom communicators and facilitators of learning. Moreover, the results show that those with low CA generally outperform those with average and high CA. This implies that if students want to excel academically, they must address their oral communication apprehensions in English. Apparently, the students could not do this alone. The teachers should likewise integrate oral communication activities that help them overcome their oral communication apprehensions. Moreover, the teachers need to provide the students more avenues to express themselves not only during discussions, but also in other communication situations.

\section{CONCLUSIONS}

In the light of the findings, it can be concluded that the teacher education students have an average level of oral communication apprehensions in English in all the communication situations and in their overall oral CA. Likewise, the majority of the students are within the average range of GWA in terms of their academic performance. Moreover, the students with low CA in classes, dyads and overall CA have significantly higher grade averages than those with average and high levels of CA.

\section{RECOMMENDATIONS}

From the conclusions drawn, it is recommended that although majority of the teacher education students have average oral communication apprehensions in English, they need to be provided with more oral communication activities to reduce their oral communication apprehensions. With this, they are able to express and explain their insights and to maximize the learning experiences they gain in participating to the different communication situations. As future teachers, they will face various communication situations. Hence, having a low CA would enable them to become better and effective communicators.

To provide opportunities for the students to reduce their oral CA level in English and to improve their academic performance, the teacher educators are encouraged to focus not just on listening activities as this would not be enough to help students overcome their apprehensions. Hence, it is recommended that the teachers have to use variety of activities, especially speaking and reading. Likewise, the teachers should make sure that their classes offer interactive discussions and that the classroom atmosphere is motivating in order to encourage their students to communicate and share their ideas freely. They should challenge their students to become better communicators by letting them explain ideas and participate in interactive exchanges of thoughts.

To gain insightful ideas on the oral communication apprehension concerns of their students, teacher-education institutions (TEIs) should occasionally get feedback from students and teachers in order to proactively offer appropriate interventions. By doing so, the TEIs could maximize the teacher-training experiences they provide to the students, as well as continuously refine their flagship education programs.

To make the curriculum more responsive to the need of developing effective oral communication skills in English of the teacher education students, curriculum developers should integrate more oral communication activities and exposure to English to enrich the teacher-training experiences of the students, which could help them overcome their apprehensions and eventually become effective communicators in their respective classrooms.

It is suggested that more studies be conducted to explore the premise of oral communication apprehensions in English to other groups of individuals, whose nature of work involves being active communicators along the different communication situations.

\section{REFERENCES}

[1] M. Castells, The Network Society: A Cross-Cultural Perspective, Cheltenham, UK, Northampton, MA: Edward Elgar Publishing, 2004.

[2] C. Crystal, English as a Global Language, $2^{\text {nd }}$ ed. Cambridge: Cambridge University Press, 2003.

[3] R. Matsuoka, "Communication apprehension among Japanese college students," Journal of Pan-Pacific Association of Applied Linguistics, vol. 12, pp. 37-48, 2008. 
[4] Partnership for $21^{\text {st }}$ Century Skills, Framework for $21^{\text {st }}$ Century Learning, 2008.

[5] Philippine Constitution, Article XIV, Section 7, 1987.

[6] Executive Order No. 210, Malacanang Palace: Philippines, 2003.

[7] K to 12 Toolkit, Department of Education: Philippines, 2012.

[8] J. McCroskey, "Oral communication apprehension: A summary of recent theory and research," Human Communication Research, vol. 4, pp. 78-96, 1977.

[9] L. Vygotsky, Thought and Language, Cambridge MA: MIT Press, 1962.

[10] D. Kolb, Experiential Learning, Englewood Cliffs, NJ: Prentice-Hall, 1984.

[11] J. McCroskey, An Introduction to Rhetorical Communication, $4^{\text {th }}$ ed. Englewood Cliffs, NJ: Prentice-Hall, 1982.

[12] M. Byrne, B. Flood, and D. Shanahan, "Communication apprehension among business and accounting students in Ireland," Irish Accounting Review, vol. 16, pp. 1-19, 2009.

[13] V. Richmond, J. Mccroskey, L. McCroskey, and J. Fayer, "Communication traits in first and second languages: Puerto Rico," Journal of Intercultural Communication Research, vol. 37, pp. 65-73, 2008.

[14] J. McCroskey, M. Beatty, P. Kearney, and T. Plax, "The content validity of the PRCA-24 as a measure of communication apprehension across communication contexts," Communication Journal, vol. 33, pp. $165-173,1985$

[15] R. Rubin, E. Graham, and J. Mignerey, "A longitudinal study of college students' communication competence," Communication Education, vol. 39, pp. 1-14, 1990.

[16] B. Berger, J. McCroskey, and V. Richmond, Communication Apprehension and Shyness, Philadelphia, PA: Lea \& Febiger, 1984.

[17] S. He and A. Chen. (2010). How to Improve Spoken English. [Online]. Available:

http://sites.google.com/site/languagejournal/Home/how-to-improve-s poken-English

[18] J. Juhana, "Psychological factors that hinder students from speaking in English class: A case study in a senior high school in South Tangerang Banten, Indonesia," Journal of Education and Practice, vol. 3, 2012.

[19] T. Hieu. (2011). Students lack Confidence to Use English. [Online]. Available: http://vietnamnews.vnagency.com.vn/Talk-Around-town /212262/Students-lack- confidence-to-use-English.html

[20] R. Kurtus. (2001). Overcome the Fear of Speaking to Group. [Online]. Available: http://www.school-for-champions.com/speaking/fear.htm

[21] S. Robby. (2010). Conquer your Fear of Making Mistakes when Speaking English. [Online]. Available: http://englishharmony.com/ conquer-fear-of-making-mistakes-when-speaking-english/

[22] C. Baldwin. (2011). How to Overcome Shyness during an Oral Presentation. [Online]. Available: http://www.ehow.com/how_78523 54_overcome-shyness-during-oral-presentation.html

[23] D. Nunan, Second Language Teaching and Learning, USA: Heinle \& Heinle Publisher, 1999.

[24] S. I. Devi and F. Shahnaz, "Oral communication apprehension and communicative competence among electrical engineering undergraduate in UTeM," Journal of Human Capital Development, pp. $1-10,2008$.

[25] N. Radzuan, and S. Kaur, "A survey of oral communication apprehension in English among ESP learners in an engineering course," English for Specific Purposes World, vol. 31, no. 10, 2010.

[26] M. A. Rojo-Laurilla, "English for maritime purposes: Communication apprehension and communicative competence among maritime students in the Philippines," Reflections on English Language Teaching, vol. 6, pp. 39-58, 2007
[27] M. Ocampo. (2014). Teacher: A great Communicator. [Online]. Available: $\quad$ http://work.chron.com/important-teachers-goodcommunication-skills-10512.html

[28] F. Silver. (2014). Why Is It Important for Teachers to Have Good Communication Skills? [Online]. Available: http://work.chron.com/ important-teachers-good-communication-skills-10512.html

[29] J. McCroskey, S. Booth-Butterfield, and S. Payne, "The impact of communication apprehension on college student retention and success," Communication Quarterly, vol. 37, no. 2, pp. 100-107, 1989.

[30] J. McCroskey and J. Andersen, "The relationship between communication apprehension and academic achievement among college students," Human Communication Research, vol. 3, no. 1, 1976.

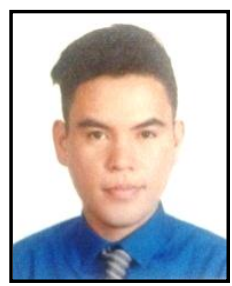

Mark Anthony T. Juan is from Laoag City, Ilocos Norte, Philippines. He was born on April 10, 1986 He earned his master of arts degree in education (MAEd) majored in English language and literature at the Mariano Marcos State University (MMSU) Graduate School, Laoag City, Philippines in 2015.

He is presently an English instructor at the Mariano Marcos State University College of Teacher Education (CTE) and Laboratory Elementary School (LES), Laoag City, Philippines. He is the unit secretary of LES, main advise of the MMSU's ABC school publication, associate editor of the CTE Research Journal, and a teacher-training instructor. His research interests include linguistics, language teaching, campus journalism, instructional materials development and integration of ICT in education.

Mr. Juan is a member of the Linguistic Society of the Philippines (LSP), Philippine Association for Teacher Education (PAFTE), and Nakem Conferences International. He was one of the recipients of the Most Outstanding School Paper Advisers of the Philippines award conferred by the Department of Education (DepEd) in 2014

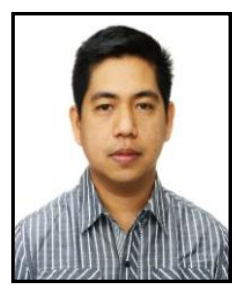

Ronald Candy S. Lasaten is from the City of Batac, Ilocos Norte, Philippines. He was born on January 16 1981. He earned his doctor of philosophy degree in applied linguistics at the Mariano Marcos State University (MMSU) Graduate School, Laoag City, Philippines in 2012

He is presently an English professor at the Mariano Marcos State University College of Teacher Education (CTE), Laoag City. He is the program adviser for English, college coordinator for Instructional Materials Development, coordinator for Board Licensure Examination for Professional Teachers (BLEPT) Review, and the head editor of the CTE Research Journal. His papers titled "English Language Needs of teachers at Bangplama Soongsumarnpadhungwit School, Suphanburi, Thailand," and "Analysis of Errors in the English Writings of Teacher Education Students," were published in the Researchers World: Journal of Arts, Science and Commerce in 2014. He also wrote a book titled Literatures of the World: Teaching and Learning in the Constructivist Approach (Quezon City: IPM Publishing, Inc., 2011). His research interests include linguistics, language, literature, language and literature teaching, language and literature assessment, instructional materials development and integration of ICT in education.

Dr. Lasaten is a member of the Linguistic Society of the Philippines (LSP), College English Teachers Association (CETA), Council of the Department Chairpersons for English (CDCE), Philippine Association for Teacher Education (PAFTE), Philippine Association for Language Teaching (PALT), Inc., and International English Learners Training Institute (IELTI) He was awarded the Outstanding Teacher of MMSU in 2014. 